\title{
Role of Rutin on Acetaminophine Induced Hepatotoxicity in Adult Male Rats
}

\author{
Walaa A.M. El-Nahrawy ${ }^{1}$, Fatma A. Abu Zahra²and Rabha E.A.EL-Dab \\ ${ }^{1}$ Zoology Department, Women's College for Arts, Science and Education - Ain \\ Shams University, Egypt \\ ${ }^{2}$ Molecular Biology and Tissue Culture, Faculty of Medicine, Medical Research \\ Center, Ain Shams University. Cairo, Egypt \\ $3^{1}$ Zoology Department, Faculty of Science, Omar AL-Moukhtar University.EL- \\ Beida,Libya. \\ *Corresponding author E-mail:
}

\begin{abstract}
The present study was designed to investigate the effect of rutin on over dose acetaminophen -induced hepatotoxicity with overdose in rats. Adult male albino rats were divided into four groups. Group 1 served as control and group2: rats received rutin .Hepatotoxicity where received induced in groups $3 \& 4$, where group 3 rats were given acetaminophen $(750 \mathrm{mg} / \mathrm{kg} \mathrm{b} . \mathrm{w})$ every $72 \mathrm{~h}$ over a period of 21 days then left for 30 days without any treatment .Group 4: rats receiving dose of acetaminophen for 21 days $(750 \mathrm{mg} / \mathrm{kg} \mathrm{b.w})$ every $72 \mathrm{~h}$ then treated orally with rutin $25 \mathrm{mg} / \mathrm{kg}$ b.w daily for 30 day.

A significant increase in the activities of liver markers enzymes, serum aminotransferase, $\gamma$-glutamyl transpeptidase , lipid peroxidation (MDA) and lipid profile and a decrease in the activities of superoxide dismutase(SOD).Rutin supplementation after acetaminophen treatment significantly decreased the levels of liver markers enzymes, lipid profile was observed and MDA while, significant elevated in the activity of liver SOD was recorded when compared with control group .
\end{abstract}

\section{Keywords}

Acetaminophine, Hepatotoxicity, Rutin, liver markers enzymes, lipid profile

\section{Introduction}

Liver is a large, organ that sits on the right side of the belly. Weighing about 3 pounds, the liver is reddish-brown in color and feels rubbery to the touch. Normally the liver can not fell it is because protected by the rib cage. The liver has two large sections, called the right and the left lobes. The gallbladder sits under the liver, along with parts of the pancreas and intestines. The liver and these organs work together to digest, absorb, and process food (Larson et al., 2005). 
Liver's main job is to filter the blood coming from the digestive tract, before passing it to the rest of the body. The liver also detoxifies chemicals and metabolizes drugs. As it does so, the liver secretes bile that ends up back in the intestines. The liver also makes proteins important for blood clotting and other functions. (Friedman, 2003; Ginès et al., 2004 and Ramón and Brenner, 2005).

Acetaminophen is commonly used analgesic and antipyretic drug that is regarded as being safe at therapeutic doses. On the other hand, when taken in excess, it produces sever hepatotoxicity, which is often fatal. Acetaminophen toxicity is one of the most common causes of poisoning worldwide and it is the most common cause of acute liver failure (Mcgill et al., 2012 and Azim et al.,2017). Toxicity from acetaminophen is not from the drug itself but from one of its metabolites, $\mathrm{N}$-acetyl-pbenzoquinoneimine (NAPQI) (Michael et al.,2012).

Large dose of A acetaminophen causes depletion of cellular glutathione (GSH) in liver as NAPQI react rapidly with GSH, which promote oxidation stress in conjunction with mitochondrial dysfunction, that lead to massive hepatocyte necrosis, liver failure or death (Imaeda et al.,2009 and Li et al.,2017).

Moreover, it is considered a predictable hepatotoxin, where biochemical signs of liver damage become apparent within 24 to 48 hours after the time of overdose (Johnkennedy and Adamma.,2011).

Many natural antioxidants have been tried for therapeutic and protective of liver against acetaminophen toxicity with different rates of success. Rutin is one of the most effective antioxidants. It is a flavonoid of the flavonol-type found in many typical plants, such as buckwheat, passion flower, apple, and tea. Moreover, it is known as vitamin $P$ that is the most abundant flavone in vegetables and fruits (Hosseinzadeh and Nassiri, 2014).

The purpose of the present study was to study the therapeutic role of rutin on acetaminophen -induced hepatotoxicity in rats.

\section{Materials and Methods}

\section{Chemicals}

Acetaminophen was orally administrated, at a dose of $(750 \mathrm{mg} / \mathrm{kg} / \mathrm{b} . \mathrm{w}$.$) evry 72 \mathrm{~h}$ daily orally for 21day (Anbarasu et al.,2011) .It was purchased from Sigma chemical Company (USA).

Rutin (RT) is soluble in distilled water and was administrated orally after acetaminophen treatment by the aid of gastric tube $(25 \mathrm{mg} / \mathrm{kg}$ b.wt) daily for 4 weeks (Shenbagam and Nalini .,2010) . 


\section{Animals}

Male adult albino rats weighting 170-150g were obtained from Animal House of El Salam Farm, Giza-Cairo, Egypt. Animal were housed in metabolic cages at temperature of $24-27^{\circ} \mathrm{C}$ at $48-54 \%$ humidity, 12 hours dark/ light cycle and received slandered food and water ad-libitum with fresh supplies presented daily .The experimental procedures complied with guidelines of the Committee on Care and use of Experimental Animal Resources, Ain Shams University, Cairo, Egypt.

\section{Experimental design}

40 male adult albino rats were allocated into for groups ten for each:

Group 1: Control rats which received distilled water.

Group 2: Rats treated orally with rutin $25 \mathrm{mg} / \mathrm{kg}$ b.w daily for 30 day.

Group 3: Rats were given acetaminophen $(750 \mathrm{mg} / \mathrm{kg}$ b.w., p.o) every $72 \mathrm{~h}$ over a period of 21 days then left for 30 days without any treatment

Group 4: Rats receiving dose of acetaminophen for 21 days $(750 \mathrm{mg} / \mathrm{kg} \mathrm{b.w})$ every 72 $\mathrm{h}$ then orally treated with rutin $25 \mathrm{mg} / \mathrm{kg}$ b.w daily for 30 day.

At the end of the experimental period, the rats were overnight fasted and sacrificed .Blood samples and liver tissue were taken into clean and dry screw capped centrifuge tubes then centrifuged at 3000rpm for 15 minutes in order to separate clear serum samples. They were then stored at $-20^{\circ} \mathrm{C}$ until used for determination of different biochemical parameters.

\section{Biochemical Analysis}

Liver enzymes (Alanin aminotransferase (ALT), aspartate aminotrasferase (AST), determined by a colorimetric method of, $\gamma$-glutamyltransferase (GGT) by the method of Szasz and Persjn (1974) were estimated by using commercial kit wpurchased from Randox,U.K.

Total cholesterol (TC), triglycerides (TG),HDL-choleaterol and LDL were determined calorimetr. The activity of superoxide dismutase (SOD) was determined according to Nishikimi et al.,(1972) ; Malondialdehyde (MDA) according to the method of Botsoglou et al.(1994). using commercial kit was purchased from Randox,U.K.

\section{STATISTICAL ANALYSIS}

Data were statistically analyzed using analysis of variance (ANOVA) followed by Duncan's multiple range test. SPSS (version 16) statistical software was used for the analysis of data and $\mathrm{P}<0.05$ was taken as the level of significance 


\section{Results}

Administration of acetaminophen markedly increased the activity of serum liver enzymes (AST, ALT, GGT) as compared to control group. The present elevation in liver enzymes were significantly decreased $(\mathrm{p}<0.05)$ in rutin group (Table 1$)$.

Furthermore, the hepatotoxicity of acetaminophen was evident from increased levels of TC and TG by about $70 \%$ and $100 \%$, respectively and increase in LDL levels accompanied by a marked decrease in the HDL-C level. On the other hand, treatment with rutin for 30 days showed remarkable reduction in the activity of AST, ALT, GGT and TC, TG, HDL \& LDL as compared to control group.

Significant decrease of liver SOD was observed in the rats treated with acetaminophen compared to control group. Moreover, the resulting increase in oxidative stress due to acetaminophen was evident by increase in MDA levels. In addition, SOD content was doubled and MDA levels were significantly decreased with rutin administration as compared with the acetaminophen group.

Table (1): Effect of treatment with rutin on liver enzymes of acetaminophen treated male rats.

\begin{tabular}{|c|c|c|c|c|}
\hline $\begin{array}{l}\text { GROUPS } \\
\text { Parameters }\end{array}$ & Control group & Rutin group & Acetaminophen group & $\begin{array}{c}\text { Acetaminophine+Ruti } \\
\text { n group }\end{array}$ \\
\hline $\begin{array}{l}\text { AST } \\
\text { (U/L) }\end{array}$ & $127.19 \pm 1.69^{A}$ & $126.12 \pm 1.02^{A}$ & $180.32 \pm 3.20^{B}$ & $158.62 \pm 1.72^{C}$ \\
\hline $\begin{array}{l}\text { ALT } \\
\text { (U/L) }\end{array}$ & $27.10 \pm 1.90^{A}$ & $28.12 \pm 1.80^{A}$ & $70.32 \pm 2.10^{B}$ & $49.21 \pm 1.52^{C}$ \\
\hline $\begin{array}{l}\text { GGT } \\
(\text { (U/L }\end{array}$ & $51.30 \pm 1.30^{A}$ & $52.31 \pm 1.10^{A}$ & $49.21 \pm 1.52^{C}$ & $29.53 \pm 1.20^{C}$ \\
\hline
\end{tabular}

Values are expressed as mean \pm SE for 10 rats/group - A, B, C, Means with a common superscript within a row are significantly different $(P<0.05)$.

Table (2): Effect of treatment with rutin on lipid profile of acetaminophen treated male rats

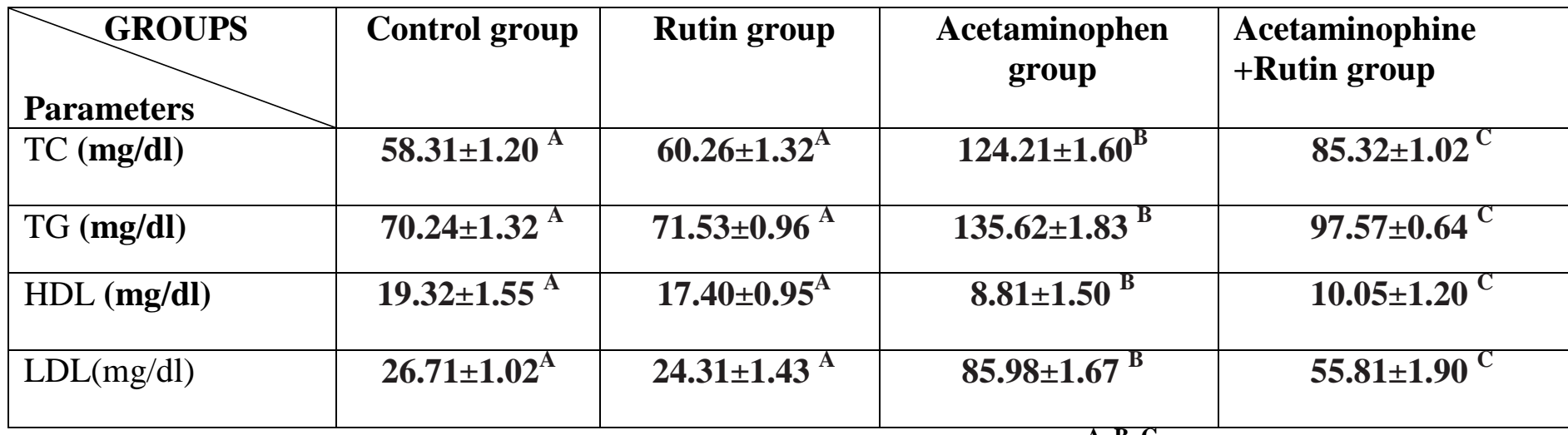

Values are expressed as mean $\pm \mathrm{SE}$ for 10 rats/group $-{ }^{A, B, C,}$ Means with a common superscript within a row are significantly different $(\mathbf{P}<0.05)$. 
Table (3): Effect of treatment with rutin on oxidative stress markers of acetaminophen treated male rats

\begin{tabular}{|c|c|c|c|c|}
\hline $\begin{array}{c}\text { GROUPS } \\
\text { Parameters }\end{array}$ & $\begin{array}{c}\text { Control } \\
\text { group }\end{array}$ & Rutin group & $\begin{array}{c}\text { Acetaminophen } \\
\text { group }\end{array}$ & $\begin{array}{l}\text { Acetaminophine } \\
+ \text { Rutin group }^{-}\end{array}$ \\
\hline $\begin{array}{c}\text { SOD } \\
\text { (U/mg protein) }\end{array}$ & $23.32 \pm 0.72^{\mathrm{A}}$ & $\mathbf{2 4 . 1 2 \pm 0 . 5 2 ^ { \mathrm { A } }}$ & $\mathbf{1 6 . 2 0 \pm 0 . 5 3 ^ { \mathrm { B } }}$ & $19.51 \pm 0.52^{\mathrm{C}}$ \\
\hline $\begin{array}{c}\text { MDA } \\
(\mathrm{m} \mu / 100 \mathrm{~g})\end{array}$ & $\mathbf{0 . 4 0 \pm 0 . 8 5 ^ { \mathrm { A } }}$ & $\mathbf{0 . 4 8} \pm 0.65^{\mathrm{A}}$ & $\mathbf{0 . 8 8} \pm 0.52^{\mathrm{B}}$ & $0.75 \pm 0.51^{\mathrm{C}}$ \\
\hline
\end{tabular}

Values are expressed as mean $\pm \mathrm{SE}$ for 10 rats/group - A, B, C, Means with a common superscript within a row are significantly different $(P<0.05)$.

\section{Discussion}

The present study provides evidence of the therapeutic role of rutin against acetaminophen induced hepatotoxicity. Increases in serum levels of ALT,AST,GGT ,TC , LDL and TG besides decrease in serum HDL as a result of acetaminophen administration are attributed to sever hepatic damage and dysfunction ( Amacher ,1998 and Sturgill et al.,1997).

Hepatocyte damage after acetaminophen treatment is an obvious sign of hepatic injury as reflected by the leakage of cellular enzymes into serum (Baldi et al., 1993 and Shenbagam\& Nalini et al., 2010). Raised levels of serum transaminases observed may be attributed to increased cell membrane permeability because of oxidative damage. Moreover, the increased activities of GGT in acetaminophen treated rats indicate permeability, damage and necrosis of hepatocytes (Chen et al.,2014).

Induction of rutin reversed the present alterations and even normalized lipid levels, indicating preservation of cellular integrity and antihyperlipidemic effect (Ashraf et al.,2012).

The role of rutin can also be attributed to its antioxidant activity, wheras the toxic effects of acetaminophen are initiated by its highly reactive metabolite, NAPQI. Moreover, acetaminophen overdose saturates detoxification pathways, resulting in GSH depletion. Subsequently, excess NAPQI , binds to cellular molecules (Romero et al.,1998), lead to lipid peroxidation, thereby propagating a chain of ROS causing an imbalance between pro-oxidants and antioxidants in body. 
Acetaminophen administration decrease hepatic antioxidant capacity evidenced by decrease activities of SOD, whereas rutin restored it even boosted its activities preventing oxidative damage (El-Sayed et al., 2015).

MDA is second product of oxidative stress formed during lipid peroxidation, which may be responsible for tissue injury. In the present study, a significant increase in MDA content was observed with acetaminophen, while treatment with rutin significantly decreased MDA level toward normal.

Moreover, it is reported that rutin induced stimulatory act on the gene expression of certain cellular enzymatic antioxidants (Nagata et al ., 1999). Flavonoid are known to induce detoxifying enzymes to enhance the excretion of toxic compounds (Helsby et al .,1997). As a flavonoid, rutin could also enhance the detoxification of acetaminophen directly from the intestines without absorption by upregulating drug metabolizing enzymes and this shows the beneficial therapeutic effect of rutin against acetaminophen -induced liver injury.

In conclusion, rutin could ameliorate hepatotoxicity induced by acetaminophen via retaining hepatic SOD, MDA contents, liver enzymes and lipid profile.

\section{Reference}

Amacher, D.E . Serum transaminase evlevations as in-dicators of hepatic injury following the administration of drugs .Regul. Toxicol. pharmacol., (2):119. (1998)

Anbarasu,C.; Rajkapoor,B.; Kalpana.J .Protective effect of Pisonia aculeata on paracetamol induced hepatotoxicity in rats.J Exp Integr Med.; 1(3): 167-172. (2011)

Ashraf,I.J.; Siddique,J.; Mirani, N. and Rub, A.Protective effect of rutin against carbon tetrachloride-induced hepatotoxicity in mice. Int.J.Drug Dev.\&Res.,4(2):352-357. (2012)

Azim, S.A.A.; Abdelrahem, M.T.; Said, M.M.and Khattab A. Protective effect of moringa peregrina leaves extract on acetaminophen induced liver toxicity in albino rats. Afr. J .Tradit .Complement. Altern. Med. 13;14(2):206-21.(2017).

Baldi, E.; Burra, P.; Plebani, M.;Salvagnini, M.Serum malondialdehyde and mitochondrial aspartate aminotransferase activity as markers of chronic alcohol intake and alcoholic liver disease. Int. J. Gastroenterol., (25): 429-432. ( 1993) 
Botsoglou,N, A.; Dimitrios,J. and Georgios, E.; Vassilios N.; Antonios, J.; Antonios, G. J. Agric. Food Chem., 42 (9), pp 1931-1937. (1994).

Chen, W.; Yang, C. and Yin, M.Protective effects from Houttuynia cordata aqueous extract against acetaminophen-induced liver injury.Biomedicine (Taipei), (1): 5, 24-28. (2014)

EL-sayed,E.M.;Mansour,A.M.,Nady,M.E.Protective effects of Pterostilbene against Acetaminophen-induced hepatotoxicity in rats.J.Biochem Molecular Toxicology,29(1), 35-46. (2015)

Friedman, S.L. Liver fibrosis - from bench to bedside. J. Hepatol., 38 (1): 38-53. (2003)

Ginès, P.; Cárdenas, A.; Arroyo, V. and Rodés, J. Management of cirrhosis and ascites. N. Engl. J. Med., 350 (16):1646-1654. (2004)

Helsby, N.; Williams, J.; Kerr, D.; Gescher, A.and Chipman, J.The isoflavones equol and genistein do not induce xenobiotic metabolizing enzymes in mouse and in human cells. Xenobiotics .; 27 587-596. (1997)

Hosseinzadeh, H.and Nassiri-Asl, M. Review of the protective effects of rutin on the metabolic function as an important dietary flavonoid. J Endocrinol Invest. 2014;37:783-8. (2014)

Imaeda, A.B.; Watanabe, A.; Sohail, M.A.; Mahmood, S.; Mohamadnejad, M.; Sutterwala, F.S.; Flavell, R.A. and Mehal, W.Z.: Acetaminophen-induced hepatotoxicity in mice is dependent on Tlr9 and the Nalp3 inflammasome. J. Clin. Invest., 119(2):305-314. (2009).

Johnkennedy,N. and Adamma,E.The protective role of Gongronema latifolium in acetaminophen induced hepatic toxicity in Wistar rats.Asian Pacific Journal of Tropical Biomedicine ,151-S154. (2011).

Larson, A.M.; Polson, J.; Fontana, R.J.; Davern, .TJ.; Lalani, E.;Hynan, L.S.; Reisch, J.S.;Schiødt, F.V.; Ostapowicz, G.; Shakil, A.O.; Lee, W.M. Acetaminopheninduced acute liver failure: results of a United States multicenter, prospective study., Hepatology, 42(6):1364-72.(2005)

Li, D.; Du, Y.; Yuan, X.; Han, X.; Dong, Z.;Chen, X.; Wu ,H.; Zhang, J.; Xu, L.; Han, C.; Zhang, M. and Xia, Q. Hepatic hypoxia-inducible factors inhibit PPAR $\alpha$ expression to exacerbate acetaminophen induced oxidative stress and hepatotoxicity. Free Radic Biol Med. , 3;110:102-116. (2017).

McGill, M.R;Williams ,C.D ; Xie, Y ;Ramachandran ,A ; Jaeschke, H. Acetaminophen-induced liver injury in rats and mice comparison of protein adducts, 
mitochondrial dysfunction, and oxidative stress in the mechanism of toxicity. Toxicol Appl Pharmacol. 1;264(3):387-94.(2012)

Michael, J.; Hodgman, M.D.; Hodgman.H.;Alexander, R.; Garrard,H.A Review of Acetaminophen Poisoning.Crit. Care. Clin 28:499-516. (2012).

Mitchel, J.R.; Jollow, D.J.; Potter, W.Z.; Gillette, J.R.; Brodie ;B.B .Acetaminopheninduced hepatic necrosis and Protective role of glutathione. J Pharmacol. Exp.;187(1):211-217. (1973).

Nagata H, Takekoshi S, Takagi T, Honma T, Watanabe K. Antioxidative action of flavonoids, quercetin and catechin, mediated by the activation of glutathione peroxidase. Tokai J. Expt. Clin. Med. 24, 1-11. (1999).

Nishikimi, M.; Appaji, N., and Yagi, K. The occurrence of superoxide anion in the reaction of reduced phenazine methosulfate and molecular oxygen. Biochem. Biophys. Res. Commun .;46(2):849-54. (1972).

Ramón, B. and Brenner, A. Liver fibrosis. J. Clin. Invest., 115(2):209-218. (2005).

Reitman,S. and Frankel,S .A colorimetric method for the determination of serum glutamic oxalacetic and glutamic pyruvic transaminases.Am. J. Clin. Pathol., Jul;28(1):56-63. (1957).

Romero, F.J.; Bosch-Morell, F.; Romero, M.J.; Jareno, E.J.; Romero, B.; Marin, N.and Roma J.Lipid per oxidation products and antioxidants in human disease. Environ Health Perspect .;5:1229-1234. (1998).

Shenbagam, M.and Nalini, N.Dose response effect of rutin a dietary antioxidant on alcohol- induced prooxidant and antioxidant imbalance - a histopathologic study .Fundamental \& clinical pharmacology,25(4), 493-502. (2011).

Sturgill, M.G.and Lambert, G.H. Xenobiotic-induced hepatotoxicity : mechanisms of liver injury and methods of monitoring hepatic function. Clin Chem; 43(8):15121526. (1997). 


\section{دور الروتن علي الأسيتامينوفين المحثث لسمية الكبد في ذكور الجرذان البالغة}

\section{ولاء أحمد مصطفي 1، فاطمة عبد الكريم أبو زهرة2 و رابحة عيسي علي الدعب3}

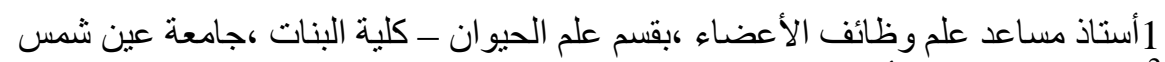

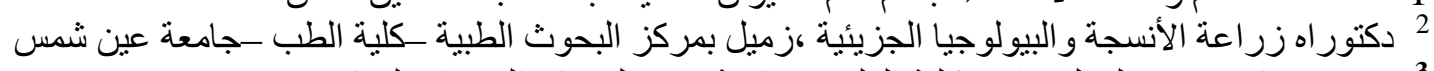

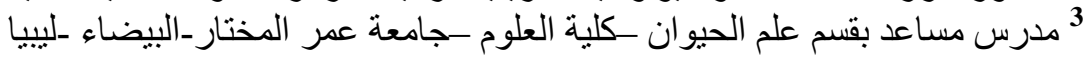

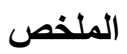

استهدف البحث دراسة المضاعفات الناتجة من استخدام عقار الأسيتامينوفين علي بعض القياسات الفسيولوجية و الدراسات النسيجية لأنسجة الكبد في ذكور الجرذان البيضاء.

ويقيم هذا البحث أيضا الدور العلاجي لمادة الروتين علي الجرذان الغير معامله وأيضا المعاملة بعقار الاسيتامينو فين للتقليل من الآثار الضارّة الناتجة من استخدام هذا العقار.

وقد تم الحصول علي نتائج من خلال مجموعة الحيو انات المعالجة ومقارنتها مع المجمو عة الضابطة، حيث تم

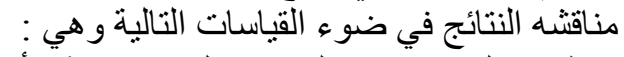

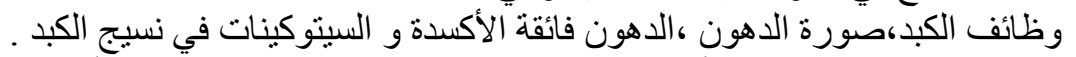

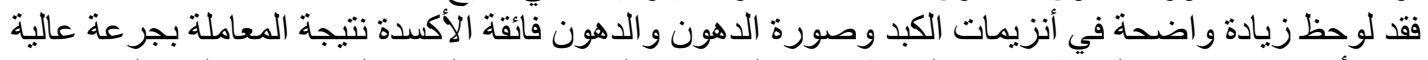

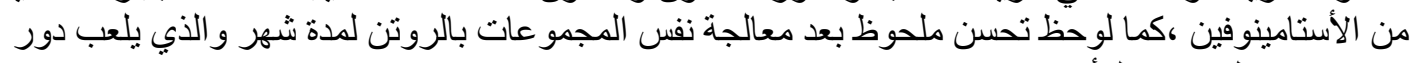
هام جدا كعامل مضاد للأكسدة.

تم مناقثة النتائج التي تم الحصول عليها و قدمت الاستتناجات و الاقتر احات لإجر اء المزيد من الدراسات. 